\title{
Suppression of powdery mildew resistance gene Pm8 in Triticum aestivum L. (common wheat) cultivars carrying wheat-rye translocation T1BL·1RS
}

\author{
RENATA HANUŠOVÁ†, SAI L. K. HSAM †, PAVEL BARTOŠ $\dagger$ \\ \& FRIEDRICH J. ZELLER* $\ddagger$ \\ $\dagger$ Research Institute of Crop Production, CZ-16106 Praha 6 - Ruzyně, Czech Republic and $\ddagger$ Technische Universität \\ München, Institut für Pflanzenbau und Pflanzenzüchtung, D-85350 Freising-Weihenstephan, Germany
}

\begin{abstract}
Disease response pattern of $127 \mathrm{~T} 1 \mathrm{~B} \cdot 1 \mathrm{RS}$ translocation and substitution wheat cultivars, possessing powdery mildew resistance gene $\operatorname{Pm} 8$ and leaf rust resistance gene $\operatorname{Lr} 26$ located on rye chromosome arm $1 \mathrm{RS}$, revealed that sixteen of these cultivars express $L r 26$, but not concomitant $P m 8$ resistance. The mode of inheritance studied in the $\mathrm{F}_{1}, \mathrm{~F}_{2}$ and $\mathrm{F}_{3}$ generations, and involving hybrids of cultivars Agra, Florida, Olymp, Sabina and Tjelvar not expressing Pm8 resistance indicated inhibition of resistance gene $P m 8$ by a dominant suppressor.
\end{abstract}

Keywords: $\operatorname{Pm} 8$ suppressor gene, powdery mildew resistance, Secale cereale, Triticum aestivum, wheat-rye translocation.

\section{Introduction}

The transfer of resistance genes from related species to common wheat (Triticum aestivum L.) has been successfully exploited in the past decades. Species that share one or two genomes with wheat such as $T$. monococcum, Aegilops squarrosa, T. timopheevii or T. turgidum and relatives such as Secale cereale, Haynaldia villosa and Agropyron that are crossable with wheat have been widely used for this purpose. However, numerous studies in Triticum have revealed that the expression of resistance is reduced when genes are transferred from lower to higher ploidy levels. This phenomenon of a 'dilution' of the resistance was reported by Kerber \& Dyck (1969, 1979) for leaf rust, Trottet et al. (1982) for leaf and stripe rust, mildew and glume blotch, Gill et al. (1986) for leaf rust, mildew, greenbug and Hessian fly, Chevre et al. (1989) for leaf and stripe rusts, Valkoun et al. (1990) for mildew and leaf rust, Siedler et al. (1994) for tan spot and Lutz et al. (1994) for powdery mildew. Moreover, there are also examples of complete suppression of resistance genes transferred from alien species to common wheat (Kerber, 1983). Rye chromosome arm 1RS widely used in wheat breeding (Villareal et al., 1991) confers resistance to various diseases. The resistance

*Correspondence.

(C) 1996 The Genetical Society of Great Britain. genes for leaf rust, stem rust, stripe rust and powdery mildew attributed to this chromosome are designated $\mathrm{Lr} 26, \mathrm{Sr} 31, \mathrm{Yr} 9$ and $\mathrm{Pm} 8$ (Singh et al., 1990; McIntosh et al., 1993).

In T. aestivum it was presumed that the expression of mildew resistance gene $P m 8$ transferred from Secale cereale (Zeller, 1973), and located on the T1BL-1RS wheat-rye interchanged chromosome was suppressed (Friebe et al., 1989, Jönsson, 1991; Hanusová, 1992; Lutz et al., 1992, 1995). The present study provides evidence of a suppressor gene of $P m 8$, and describes its mode of inheritance.

\section{Materials and methods}

A total of 127 wheat cultivars and lines possessing a T1BL-1RS translocation or substitution were tested for their disease response at the seedling stage. The presence of resistance genes $P m 8$ and $L r 26$ was scored after inoculation with their respective pathogenic isolates. Two single-pustule-derived Erysiphe graminis tritici (Egt) isolates Nos 47 and 58, avirulent to $P m 8$, and one Puccinia recondita tritici (Prt) isolate, No. 243, avirulent to $L r 26$, maintained at Prague-Ruzyne, were initially used to verify the presence of genes $P m 8$ and $L r 26$, respectively. The virulence of these isolates to other resistance genes of the standard differential cultivars and the method used have been described previously by Hanušová (1992). 
After the initial crosses between selected cultivars, seeds of the various filial generations were tested at one of two locations either at Prague-Ruzyne, or in Weihenstephan. Tests for resistance in Weihenstephan were carried out on segments of primary leaves of host plants. The leaf detachment method employed was described previously by Zeller et al. (1993) using leaf segments cultured in petri dishes on $6 \mathrm{~g} \mathrm{~L}^{-1}$ agar and $35 \mathrm{mg} \mathrm{L}^{-1}$ benzimidazole. Egt isolates Nos 2 and 17 are avirulent to $P m 8$, but possessing differential virulences to other $\mathrm{Pm}$ genes present in the standard set of test cultivars (Lutz et al., 1992). Prt isolate No. L-13 is avirulent to leaf rust resistance gene $\operatorname{Lr} 26$. Somatic chromosomes of the 127 wheat cultivars and lines were also studied by the standard Feulgen method for detection of the number of satellited chromosome pairs (1B, 6B).

Five cultivars, Agra, Florida, Olymp, Sabina and Tjelvar, which possess the T1BL-1RS translocated chromosome and express $\operatorname{Lr} 26$, but not $\operatorname{Pm} 8$ resistance were crossed to cultivars Vala, Hana and Viginta lacking both $P m 8$ and $L r 26$. The hybrids Agra/Vala, Florida/Hana, Sabina/Hana, Tjelvar/ Hana and Olymp/Viginta were studied in the $F_{1}, F_{2}$ and $F_{3}$ generations. Fifty to sixty $F_{2}$ plants randomly selected from each hybrid combination were propagated to form $F_{3}$ populations. However, several $F_{3}$ families did not produce sufficient amount of seeds and were excluded. The hybrid combinations Disponent/Olymp, Disponent/Florida and Disponent/ Sabina were studied for the disease resistance to Pm8 and $L r 26$ in the $F_{1}$ and $F_{2}$ generations. The hybrid combinations Agra/Sabina, Florida/Sabina, Agra/Olymp, Olymp/Sabina, Tjelvar/Sabina and Tjelvar/Olymp, all presumably possessing suppressors, were evaluated in the $F_{1}$ and $F_{2}$ generations for $P m 8$ resistance to assess the identity of the suppressing factor.

The different Egt and Prt isolates used in the present study were selected for their abilities to differentiate the reponse patterns of the parental cultivars for resistance to $\operatorname{Pm} 8$ and $\operatorname{Lr} 26$. Disponent showed resistance response to the various Egt and Prt isolates used. Cultivars Agra, Florida, Olymp, Sabina and Tjelvar were resistant to both Prt isolates, but susceptible to all Egt isolates. Cultivars Hana, Vala and Viginta exhibited susceptible reactions to all Egt and Prt isolates used.

\section{Results and discussion}

The 127 common wheat cultivars and lines which were assumed to carry a $\mathrm{T} 1 \mathrm{BL} \cdot 1 \mathrm{RS}$ wheat-rye translocation or substitution, were found to possess only two satellited chromosomes by mitotic analysis. This infers that the short arm of one satellited chromosome pair, presumably $1 \mathrm{~B}$, had been replaced by the $1 \mathrm{RS}$ rye chromosome arm.

From the set of cultivars tested against $\mathrm{Egt}$ isolates Nos 47 and 58, and a Prt isolate No. 243, avirulent to $L r 26,111$ cultivars were resistant to $\mathrm{Egt}$ and Prt isolates inferring that $P m 8$ and $L r 26$ are located on chromosome arm 1RS, as all resistant individuals carry this translocation. Sixteen T1B1·1RS carriers showed the presence of resistance gene $L r 26$, but did not express $P m 8$ resistance, suggesting that a suppression mechanism is in operation (Table 1). Five of the cultivars which show Lr26 resistance but lack $P m 8$ resistance, Agra, Florida, Sabina, Tjelvar and Olymp, were crossed with $P m 8$ susceptible cultivars Vala, Hana and Viginta. Hence both parents in each cross combination showed susceptibility to powdery mildew pathogens. As seen in Table 2 all the $F_{1}$ generations also revealed susceptible response to $\operatorname{Pm} 8$ avirulent isolates Nos 2, 47 and 203, respectively. However, the $F_{2}$ generation derived from susceptible $F_{1}$ hybrids segregated resistant and susceptible plants in the crosses Agra/ Vala, Florida/Hana, Tjelvar/Hana which conformed to a ratio of 3 resistant:13 susceptible. The results showed that the resistance gene $P m 8$ was not expressed in the presence of a suppressor gene in the $F_{1}$ generation. However, segregants in the $F_{2}$ generation, possessing the $P m 8$ gene in the absence of the dominant suppressor segregated into the 3 resistant class, whereas those carrying $P m 8$ in combination with the suppressor, as well as the homozygous recessive individuals lacking both $\mathrm{Pm} 8$ and the suppressor were susceptible and segregated as the 13 susceptible class. The $F_{2}$ mode of inheritance from hybrid combinations between mildew susceptible cultivars possessing the T1BL-1RS translocation and other susceptible parents indicated the presence of the $P m 8$ gene that was suppressed in the parents, but the resistance was again detected in the $\mathrm{F}_{2}$ segregants. The $\mathrm{F}_{2}$ segregation from the hybrids Sabina/Hana and Olymp/Viginta deviated from the 3:13 genetic ratio (Table 2). In these cross combinations more susceptible individuals were observed than the expected numbers. It had been previously reported that gametic transfer of the T1BL-1RS translocated chromosome may vary between different hybrid combinations (Mettin et al., 1973), resulting in more susceptible $\mathrm{F}_{2}$ individuals when the resistance gene in question is on the 1RS chromosome arm (Wienhues, 1965; Bartoš \& Bareš, 1971; Bartoš, 1993).

The $F_{3}$ lines derived from $F_{2}$ plants segregated 
Table 1 Genealogies of 16 wheat cultivars carrying wheat-rye translocation T1BL-1RS which possess $L r 26$ leaf rust resistance, but not expressing $P m 8$ powdery mildew resistance

\begin{tabular}{lll}
\hline Cultivar/line & Country & Pedigree† \\
\hline Agra & Czech Republic & Avrora/S985//Purdue 66278 \\
Druzba & CIS & Winnetou/Heine//Leone \\
Feldkrone & Germany & Heines VII/Taca//Rieti/3/Taca/4/Zorba \\
Florida & Germany & Caribo/Disponent \\
Ikarus & Austria & Caribo/Weihenstephan Stamm 623-65 \\
Istra & Czech Republic & S958/Avrora \\
Kalojan & Bulgaria & Snem/Avrora//Rusalka \\
Lovrin 10 & Romania & Abbondanza/Triumph//Bezostaya 1 \\
Lovrin 24 & Romania & Lovrin 10/Lovrin 62 \\
Olymp & Germany & Mex./ Götz//Kronjuwel(Götz: Tenor/2xJubilar//Benno) \\
Palur & Germany & Hadm.05792-71/Hadm.03924-63/ 2x//Suwon/3/2xAlmus \\
Riebesel 47/51 & Germany & Criewener 104/Petkus rye \\
Sabina & Czech Republic & Weihenstephan Stamm 378-57 132b/Caribo \\
Skorospelka 35 & CIS & Erythrospermum 315-N-60/Bezostaya 1 \\
Tjelvar & Sweden & WW 20999/Benno \\
Yugoslavija & Former Yugoslavia & NS 646/Bezostaya 1//Avrora \\
\hline
\end{tabular}

$\dagger$ Information partly obtained from Zeven \& Zeven-Hissink (1976).

$\$(1 \mathrm{R} / 1 \mathrm{~B})$ wheat-rye substitution line (Zeller, 1973).

Table 2 Genetic analyses of wheat cultivars Agra, Florida, Sabina, Tjelvar and Olymp carrying wheatrye translocation $\mathrm{T} 1 \mathrm{BL} \cdot 1 \mathrm{RS}$ but not expressing powdery mildew resistance in crosses with $P m 8$ susceptible cultivars

\begin{tabular}{|c|c|c|c|c|c|c|c|c|}
\hline \multirow{2}{*}{$\begin{array}{l}\text { Hybrid and } \\
\text { generation }\end{array}$} & \multirow{2}{*}{$\begin{array}{c}\text { Isolate } \\
\text { no. }\end{array}$} & \multicolumn{4}{|c|}{ Numbers of plants/lines } & \multirow{2}{*}{$\begin{array}{l}\text { Expected } \\
\text { ratio }\end{array}$} & \multirow[b]{2}{*}{$\chi^{2}$} & \multirow[b]{2}{*}{$P$} \\
\hline & & Res. & Susc. & Segr. & Total & & & \\
\hline \multicolumn{9}{|l|}{ Agra/Vala } \\
\hline $\mathrm{F}_{1}$ & 47 & 0 & 5 & 0 & 5 & & & \\
\hline $\mathrm{F}_{2}$ & 47 & 24 & 87 & 0 & 111 & $3: 13$ & 0.61 & $0.5-0.2$ \\
\hline $\mathrm{F}_{3}$ & 47 & 3 & 19 & 26 & 48 & $1: 7: 8$ & 0.34 & $0.9-0.8$ \\
\hline \multicolumn{9}{|l|}{ Florida/Hana } \\
\hline $\mathrm{F}_{1}$ & 203 & 0 & 9 & 0 & 9 & & & \\
\hline $\mathrm{F}_{2}$ & 2 & 17 & 79 & 0 & 96 & $3: 13$ & 0.07 & $0.8-0.7$ \\
\hline $\mathrm{F}_{3}$ & 203 & 2 & 24 & 24 & 50 & $1: 7: 8$ & 0.66 & $0.8-0.7$ \\
\hline \multicolumn{9}{|l|}{ Sabina/Hana } \\
\hline $\mathrm{F}_{1}$ & 2 & 0 & 5 & 0 & 5 & & & \\
\hline $\mathrm{F}_{2}$ & 2 & 16 & 288 & 0 & 304 & $3: 13$ & 36.3 & 0.01 \\
\hline $\mathrm{F}_{3}$ & 203 & 0 & 20 & 10 & 30 & $1: 7: 8$ & 7.14 & $0.05-0.02$ \\
\hline \multicolumn{9}{|l|}{ Tjelvar/Hana } \\
\hline$F_{1}$ & 2 & 0 & 4 & 0 & 4 & & & \\
\hline $\mathrm{F}_{2}$ & 2 & 43 & 205 & 0 & 248 & $3: 13$ & 0.32 & $0.7-0.5$ \\
\hline $\mathrm{F}_{3}$ & 2 & 1 & 9 & 12 & 22 & $1: 7: 8$ & 2.57 & $0.3-0.2$ \\
\hline \multicolumn{9}{|c|}{ Olymp/Viginta } \\
\hline $\mathrm{F}_{1}$ & 2 & 0 & 5 & 0 & 5 & & & \\
\hline $\mathrm{F}_{2}$ & 2 & 4 & 161 & 0 & 165 & $3: 13$ & 23.5 & 0.01 \\
\hline $\mathrm{F}_{3}$ & 2 & 0 & 11 & 17 & 28 & $1: 7: 8$ & 2.46 & $0.3-0.2$ \\
\hline
\end{tabular}

Res., resistant; Susc., susceptible; Segr., segregating. into three groups: resistant, susceptible and segregating families. The $\mathrm{F}_{3}$ lines derived from the crosses of Agra/Vala, Florida/Hana and Tjelvar/Hana corresponded to a ratio of 1 res:7sus:8seg. However, complete resistance families in the $\mathrm{F}_{3}$ lines were not detected in the crosses between Sabina/Hana and Olymp/Viginta. It is likely that during the random propagation of limited numbers of $\mathrm{F}_{2}$ plants for 
derivation of $\mathrm{F}_{3}$ families, homozygous resistant plants were not included. Nevertheless, the segregation ratio in the $F_{3}$ generation in these crosses provided further evidence of a suppressor gene that inhibited the expression of mildew resistance gene Pm8.

The $\mathrm{F}_{2}$ generation derived from crosses involving cultivars Olymp, Florida and Sabina expressing Lr26, but not $P m 8$ resistance, and Disponent with both Lr26 and Pm8 resistances were tested against Prt isolate No. L-13, avirulent to Lr26, and Egt isolate No. 17, avirulent to $P m 8$. Segments from primary leaves of each individual were inoculated with either Egt or Prt isolates. As expected, all $\mathrm{F}_{2}$ plants were resistant to $P r t$ isolate L-13 confirming that cultivars Olymp, Florida and Sabina possess the same Lr26 gene as Disponent. However, the same plants simultaneously tested for $P m 8$ segregated into mildew resistant and mildew susceptible individuals corresponding to a ratio of 1 res:3sus (Table 3 ). This ratio revealed that the suppressor segregated as a dominant gene and that $P m 8$, inherited from both parents, was expressed only in the absence of the suppressor. The concomitant test for two genes, namely $P m 8$ and $L r 26$ located on the same translocated chromosome arm served as useful genetic markers, and revealed that in these cross combinations gametic transfer of $L r 26$ was normal as expected. Because of the location of these two genes, aberrant gametic transfer of T1BL 1 RS could be ruled out for the nonexpression of resistance, hence segregation for $P m 8$ resistance resulted from the action of the suppressor gene.

No mildew-resistant plants were found in crosses Agra/Sabina (5 $\mathrm{F}_{1} ; 335 \mathrm{~F}_{2}$ plants), Florida/Sabina
(10 $\mathrm{F}_{1} ; 320 \mathrm{~F}_{2}$ plants), Agra/Olymp (7 $\mathrm{F}_{1} ; 79 \mathrm{~F}_{2}$ plants), Olymp/Sabina ( $8 \mathrm{~F}_{1} ; 87 \mathrm{~F}_{2}$ plants), Tjelvar/ Sabina $\left(8 \mathrm{~F}_{1} ; 91 \mathrm{~F}_{2}\right.$ plants) or Tjelvar/Olymp $\left(8 \mathrm{~F}_{1}\right.$; $95 \mathrm{~F}_{2}$ plants). This indicates that these cultivars possess the same suppressor gene. The presence of a suppressor gene for $\mathrm{Pm} 8$ was also detected in Australia in derivative lines possessing a T1BL $1 \mathrm{RS}$ translocation. The suppressor gene was designated SuPm8 (R. A. McIntosh, personal communication).

The powdery mildew resistance gene $P m 8$ located on rye chromosome $1 \mathrm{RS}$ was introduced into common wheat by hybridization of $T$. aestivum with $S$. cereale, developed independently in Salzmünde and Weihenstephan, Germany (Zeller, 1973). Nonexpression of $P m 8$ resistance has been described by Friebe et al. (1989), Jönsson (1991), Hanušová (1992) and Lutz et al. (1992, 1995). In the transfer of leaf rust, stem rust and stripe rust resistance genes from alien species (e.g. Aegilops squar-rosa, Triticum dicoccoides) to common wheat Kerber \& Green (1980), Bai \& Knott (1992), Kema et al. (1995) and Ma et al. (1995) have also provided evidence that incorporated resistance genes can be suppressed by gene(s) located in the wheat genome. In spite of the existence of suppressors of resistance that may limit the potential use of tranferred alien genes, several studies advocate that alien genetic variation could be successfully exploited. Thus germplasm resources from remote relatives of wheat may still serve as a vast genetic reservoir for future wheat improvement.

\section{Acknowledgements}

We thank Dr F. Felsenstein and Ildikó Bellovics for their help in disease reaction studies. Financial

Table 3 Genetic analysis of wheat cultivars Olymp, Florida and Sabina carrying wheat-rye translocation T1BL· 1 RS which express $L r 26$, but lacking $P m 8$ powdery mildew resistance in hybrids with $P m 8$ and $L r 26$ resistant cultivar Disponent

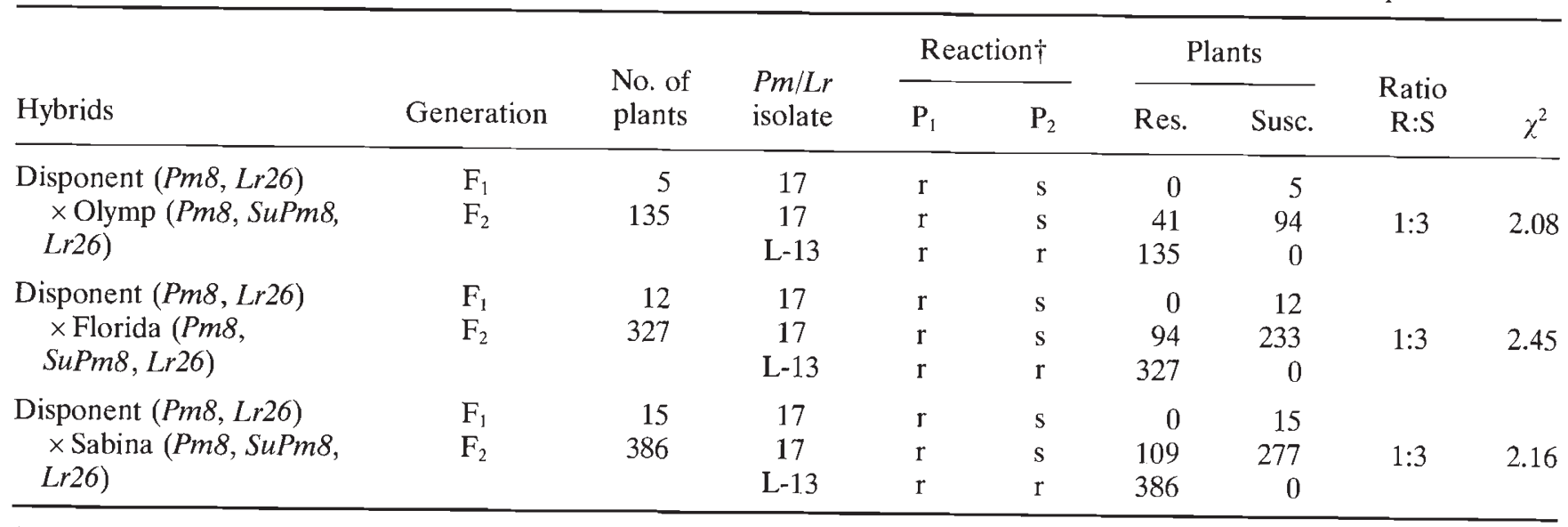

$\nmid \mathrm{r}$, resistant; s, susceptible. 
supports by Volkswagen Stiftung, Hannover, (I 68 922) and Deutsche Forschungsgemeinschaft ( $\mathrm{Ze}$ 132/14-1) are gratefully acknowledged.

\section{References}

BAI, D. AND KNOTT, D. R. 1992. Suppression of rust resistance in bread wheat (Triticum aestivum L.) by D-genome chromosomes. Genome, 35, 276-282.

BARTO s, P. 1993. Chromosome $1 \mathrm{R}$ of rye in wheat breeding. Pl. Breed. Abst., 63, 1203-1211.

BARTOŠ, P. AND BAREŠ, 1. 1971. Leaf and stem rust resistance of hexaploid wheat cultivars Salzmünder Bartweizen and Weique. Euphytica, 20, 435-440.

CHEVRE, A. M., JAHIER, J. AND TROTTET, M. 1989. Expression of disease resistance genes in amphiploid wheatsTriticum tauschii (Coss.) Schmal. Cereal Res. Comm., 17, 23-29.

FRIEBE, B., HEUN, M. AND BUSHUK, w. 1989. Cytological characterization, powdery mildew resistance and storage protein composition of tetraploid and hexaploid $1 \mathrm{BL} / 1 \mathrm{RS}$ wheat-rye translocation lines. Theor. Appl. Genet., 78, 425-432.

GILl, B. S., RAUPP, w. J., ShaRma, H. C., BROUDER, L. E., HATCHETT, J. H., HARVEY, T. L. ET AL. 1986. Resistance in Aegilops squarrosa to wheat leaf rust, wheat powdery mildew, green bug and Hessian fly. Pl. Dis., 70, $553-556$.

HANUŠOVÁ, R. 1992. Powdery mildew resistance of wheat cultivars with $1 \mathrm{~B} / 1 \mathrm{R}$ translocation/substitution. Proceedings of the 8th European Mediterranean Cereal Rusts Mildews Conference, Vorträge Pflanzenzüchtg, 24, pp. 237-238.

Jösson, J. Ö. 1991. Wheat breeding against facultative pathogens. Sverig. Utsädesf. Tidsk., 101, 89-93.

KERBER, E. R. 1983. Suppression of rust resistance in amphiploids of Triticum. Proceedings of the 6th International Wheat Genetics Symposium, Kyoto, Japan, pp. 813-817.

KERBER, E. R. AND DYCK, P. L. 1969. Inheritance in hexaploid wheat of leaf rust resistance and other characters derived from Aegilops squarrosa. Can. J. Genet. Cytol., 11, 639-647.

KERBER, E. R. AND DYCK, P. L. 1979. Resistance of stem and leaf rust of wheat in Aegilops squarrosa and transfer of a gene for stem rust resistance to hexaploid wheat. Proceedings of the 5th International Wheat Genetics Symposium, New Delhi, India, pp. 358-364.

KERBER, E. R. AND GREEN, G. J. 1980. Suppression of stem rust resistance in the hexaploid wheat $\mathrm{cv}$. Canthatch by chromosome 7DL. Can. J. Bot., 58, 1347-1350.

KEMA, G. H. J., LANGE, w. AND SILFHOUT, C. H. VAN, 1995. Differential suppression of stripe rust resistance in synthetic wheat hexaploids derived from Triticum turgidum subsp. dicoccoides and Aegilops squarrosa. Phytopathology, 85, 425-429.

LUTZ, J., LIMPERT, E., BARTOŠ, P. AND ZELLER, F. J. 1992. Identification of powdery mildew resistance genes in common wheat (Triticum aestivum L.). I. Czechoslovakian cultivars. $P l$. Breed., 108, 33-39.

LUTZ, J., HSAM, S. L. K., LIMPERT, E. AND ZELLER, F. J. 1994. Powdery mildew resistance in Aegilops tauschii Coss. and synthetic hexaploid wheat. Genet. Res. Crop Evol., 41, 151-158.

LUTZ, J., KATZHAMMER, M., STEPHAN, U., FELSENSTE1N, F. G., OPPITZ, K. AND ZELlER, F. J. 1995. Identification of powdery mildew resistance genes in common wheat (Triticum aestivum L. em. Thell.). V. Old German cultivars and cultivars released in the former GDR. $P l$. Breed., 114, 29-33.

MA, H., SINGH, R. P. AND MUJEEB-KAZI, A. 1995. Suppression/expression of resistance to stripe rust in synthetic hexaploid wheat (Triticum turgidum $\times T$. tauschii). Euphytica, 83, 87-93.

McINTOSH, R. A., HART, G. AND GALE, M. 1993. Catalogue of gene symbols for wheat. In: Proceedings of the 6th International Wheat Genetics Symposium, Beijing, China, pp. 1333-1500.

METT1N, D., BLÜthNER, w. D. AND SCHLEGEL, G. 1973. Additional evidence on spontaneous $1 \mathrm{BL} / 1 \mathrm{RS}$ wheatrye substitution. In: Proceedings of the 4th International Wheat Genetics Symposium, Columbia, USA, pp. 179-184.

SIEDLER, H., OBST, A., HSAM, S. L. K. AND ZELLER, F. J. 1994. Evaluation for resistance to Pyrenophora tritici-repentis in Aegilops tauschii Coss. and synthetic hexaploid wheat amphiploids. Genet. Res. Crop Evol., 41, 27-34.

SINGH, N. K., SHEPHERD, K. W. AND McINTOSH, R. A. 1990. Linkage mapping of genes for resistance to leaf, stem and stripe rusts and $\omega$-secalins on the short arm of rye chromosome 1R. Theor. Appl. Genet., 80, 609-616.

TROTTET, J., JAHIER, J. AND TANGUY, A. M. 1982. A study of an amphiploid between Aegilops squarrosa Tausch. and Triticum dicoccum Schübl. Cereal Res. Comm., 10, 55-59.

VAlkoun, J., DOSTÁL, J. AND KuČEROVÁ, D. 1990. Triticum $\times$ Aegilops hybrids through embryo culture. In: Bajaj, Y.P.S. (ed.) Biotechnology in Agriculture and Forestry, 13, Wheat, pp. 152-166. Springer, Berlin.

VILLAREAL, R. L., MUJEEB-KAZI, A., RAJARAM, S. AND DEL-TORO, E. 1991. The effects of chromosome 1B/1R translocation on the yield potential of certain spring wheats (Triticum aestivum L.) Pl. Breed., 106, 77-81.

WIENHUES, A. 1965. Cytogenetische Untersuchungen über die chromosomale Grundlage der Rostresistenz der Weizensorte Weique. Züchter, 35, 352-354.

ZELLER, F. J. 1973. 1B/1R wheat-rye chromosome substitutions and translocations. Proceedings of the 4th International Wheat Genetics Symposium, Columbia, USA, pp. 209-221.

ZELLER, F. J., LUTZ, J., REMLEIN, E. I., LIMPERT, E. AND KOENIG, J. 1993. Identification of powdery mildew resistance genes in common wheat (Triticum aestivum L.). II. French cultivars. Agronomie, 13, 201-207.

ZEVEN, A. C. AND ZEVEN-HISSINK, N. C. 1976. Genealogies of 14,000 wheat varieties. Netherlands Cereal Centre, Wageningen. 